
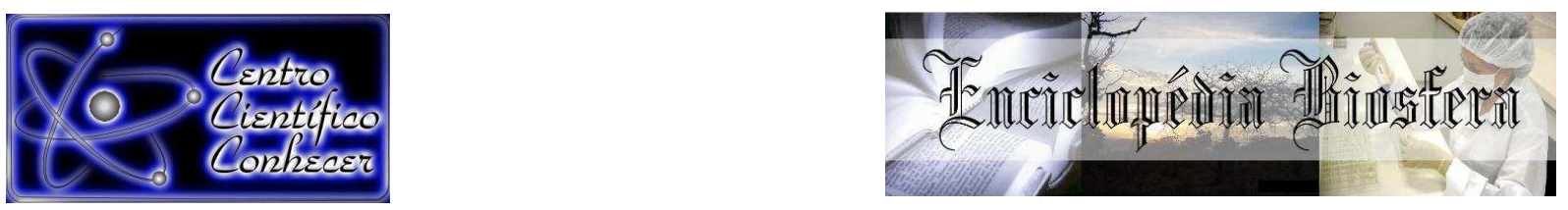

\title{
QUALIDADE FÍSICO-QUÍMICA E BACTERIOLÓGICA DA ÁGUA QUE ABASTECE O ASSENTAMENTO CANUDOS, MUNICÍPIO DE PALMEIRAS DE GOIÁS
}

\footnotetext{
Samara Rodrigues Machado', Fernanda Rodrigues Mendes², Eliete Souza Santana ${ }^{3}$, Osvaldo José da Silveira Neto ${ }^{4}$, Nayra Rodrigues de Alcântara ${ }^{5}$

${ }^{1}$ Graduanda do Curso de Ciências Biológicas da Universidade Estadual de Goiás;

${ }^{2}$ Docente e Orientadora da Universidade Estadual de Goiás, Palmeiras de Goiás, GO (in memorian);

${ }^{3}$ Docente Universidade Estadual de Goiás, Palmeiras de Goiás, GO (elietessouza@yahoo.com.br);

${ }^{4}$ Docente da Universidade Estadual de Goiás, São Luís dos Montes Belos, GO;

${ }^{5}$ Bióloga e Técnica de Laboratório da Universidade Estadual de Goiás, Palmeiras de Goiás, GO
}

\section{Recebido em: 08/09/2015 - Aprovado em: 14/11/2015 - Publicado em: 01/12/2015 DOI: http://dx.doi.org/10.18677/Enciclopedia_Biosfera_2015_028}

\begin{abstract}
Objetivou-se com este estudo verificar a qualidade físico-química $(\mathrm{pH})$ e bacteriológica da água destinada ao consumo dos moradores do assentamento de Canudos localizado na região de Palmeiras de Goiás. Foram coletadas 60 amostras da água utilizada pelos moradores do assentamento, as quais foram realizadas aleatoriamente, em cada propriedade, aplicou-se paralelamente um questionário buscando informações sobre o destino da água, limpeza dos poços e animais criados na propriedade. Observou-se a presença de Escherichia coli, Aeromonas e Pseudomonas sp. na água que abastece $\mathrm{o}$ assentamento. $\mathrm{O} \mathrm{pH}$ da água esteve dentro dos padrões de normalidades exigido pelo Ministério da saúde. Concluiu-se que a maioria dos moradores do assentamento realizam a limpeza dos poços anualmente. A água destinada para o consumo das famílias também é destinada para consumo dos animais e manutenção de hortaliças cultivadas nas propriedades.
\end{abstract}

RESUMO

PALAVRAS-CHAVE: água, bactérias, contaminação, poços, pH

\section{QUALITY PHYSICAL CHEMISTRY AND WATER BACTERIOLOGICAL THAT FUELS THE SETTLEMENT CANUDOS, MUNICIPALITY OF PALMEIRAS OF GOIAS}

\section{ABSTRACT}

The objective of this study verify the physico-chemical $(\mathrm{pH})$ and bacteriological water intended for the residents of the settlement of Straws, Palmeiras de Goiás region were collected 60 samples of the water used by residents of the settlement. Samples were collected randomly in the settlement, and in each property, applied parallel a questionnaire seeking information about the fate of water, cleaning of wells and livestock 
grown on the property. It was observed the presence of Escherichia coli, Aeromonas and Pseudomonas sp. the water supply of the settlement. The $\mathrm{pH}$ of the water is within the standards of normality required by the Ministry of Health. It was concluded that most of the residents of the settlement perform the cleaning of wells annually. Water used for household consumption is also intended for consumption by animals and vegetables grown in the maintenance of properties.

KEYWORDS: water, bacteria, contamination, wells, $\mathrm{Ph}$

\section{INTRODUÇÃO}

A água é um elemento essencial à vida. O funcionamento do organismo humano depende de forma imprescindível da presença da água, de modo que distribui nutrientes pelos diferentes órgãos, ajuda a regular a temperatura do corpo, eliminar as toxinas por meio da urina e da transpiração, além de estimular o trânsito intestinal. Desse modo, quando há pouca água no corpo, o organismo sofre prejuízos (CASTRO et al., 2010). Ademais, o cérebro é constituído por aproximadamente $85 \%$ de água e todo o corpo humano por 75\% (YAMAGUCHI et al., 2013).

Estima-se que cerca de $70 \%$ da superfície do planeta Terra é constituído por água, onde $3 \%$ são de água doce, e desse total $98 \%$ é água subterrânea. Com aproximadamente 1,4 milhões de quilômetros cúbicos de água, apenas $2,5 \%$ são de natureza doce, os lugares de onde os seres humanos retiram o que consomem, correspondem a apenas $0,26 \%$ desse percentual. A água disponibilizada para consumo que são destinadas ao abastecimento público, é em torno de $10 \%, 23 \%$ vai para a indústria e 67\% para a agricultura (GOMES, 2011).

Durante séculos, considerou-se que as fontes de água eram inesgotáveis, porém, a população mundial aumenta assim como a urbanização, a industrialização, o desenvolvimento tecnológico e agrícola, e consequentemente a demanda por água. $\mathrm{A}$ qual tem mantido constante a sua quantidade (LIMA et al., 2011).

De acordo com o manual do centro CETESB (2015) a água é fundamental em diversas atividades como o abastecimento público, geração de energia elétrica, navegação, dessedentação de animais, suprimento industrial, crescimento de culturas agrícolas, conservação da flora e da fauna, recreação e lazer, criação de espécies e harmonia paisagística. É também responsável pelo transporte e diluição de despejos, através de processos físicos, químicos e biológicos.

Para o abastecimento doméstico a água deve apresentar características sanitárias e toxicológicas adequadas, não apresentando microrganismos patogênicos e substâncias nocivas à saúde, com o intuito de prevenir danos e promover o bem-estar das pessoas (ARAÚJO et al., 2011).

Os agentes biológicos encontrados em águas contaminadas são as bactérias patogênicas, os vírus e os parasitas. As bactérias constituem uma das principais fontes de morbidade (KEMERICHK \& SAUCEDO, 2011). Os agentes patogênicos encontrados na água causam infecções do trato intestinal como, febre tifóide, disenteria bacilar, amebíase e cólera. Sendo encontradas com maior incidência em comunidades de baixa renda que vivem em locais com infraestrutura precária (SANTOS et al., 2013).

As doenças transmitidas através da água ocorrem principalmente em áreas rurais e subúrbios das grandes cidades, devido a inadequadas condições de saneamento e a falta de informações por parte da população. Acometendo 
principalmente crianças e jovens, prejudicando o desenvolvimento físico e mental, e diminuindo o rendimento escolar e a produtividade no trabalho (ARAÚJO et al., 2011).

A água subterrânea é utilizada por $19 \%$ da população brasileira, sendo captada de forma precária (RHEINHEIMER et al., 2010). Os métodos utilizados para captação de água subterrânea são os poços artesianos que se encontram entre duas camadas relativamente impermeáveis que auxiliam para que não ocorra contaminação com facilidade. $E$ também poços rasos que estão mais próximos da superfície e mais suscetíveis a contaminações, porém, este é o mais utilizado devido ao baixo custo e facilidade de perfuração (SILVA \& ARAUJO 2003).

$\mathrm{Na}$ zona rural a principal fonte de abastecimento de água são os lençóis superficiais, que propicia 0 desenvolvimento de microrganismos patogênicos (BANDEIRA et al., 2011). A adubação de culturas com fertilizantes químicos e orgânicos pode contaminar as fontes de captação de água na zona rural (NUNES et al., 2010). Os dejetos de suínos são muito utilizados como adubo orgânico, e quando aplicado em grande quantidade de maneira que as plantas não conseguem absorver todo o nutriente oferecido, pode acarretar na contaminação das águas subterrâneas (CASSOL et al., 2011).

A Organização Mundial de Saúde publicou um levantamento mostrando que investimentos no tratamento da água poderiam economizar grande quantidade de recursos públicos, evitando gastos de US\$ 7 bilhões por ano, se os governos dobrassem os investimentos com tratamento de água e com isso obteria redução de gastos com a saúde, onde o mundo ganharia US\$ 84 bilhões por ano (AGÊNCIA ESTADO, 2008).

O presente trabalho teve como objetivo analisar a qualidade físico-química e bacteriológica da água de poços rasos ou artesianos utilizados pela população do assentamento Canudos pertencente ao município de Palmeiras de Goiás.

\section{MATERIAL E MÉTODOS}

\section{CARACTERIZAÇÃO DA ÁREA}

O assentamento Canudos está localizado no estado de Goiás sob as coordenadas $16^{\circ} 52^{\prime} 40.20^{\prime \prime} S$ e $49^{\circ} 43^{\prime} 48.10^{\prime \prime} \mathrm{O}$, di stribuído nos municípios de: Campestre, Guapó e Palmeiras de Goiás. A região pertencente ao assentamento encontra-se privilegiada pela proximidade da capital goiana, com aproximadamente 100 km de distância (INCRA GOIAS, 2011).

Possui 12.771,94 hectares de terras, dos quais a reserva florestal chega a $54,08 \%$ (CARVALHO et al., 2007). Os lotes do assentamento possuem medidas que variam entre 15 a 18 hectares, distribuídos entre 330 famílias assentadas, onde 120 desses assentados estão sediados no município de Palmeiras de Goiás a aproximadamente 20 a $30 \mathrm{~km}$. A atividade predominante no local é a agricultura familiar (Figura 1). 


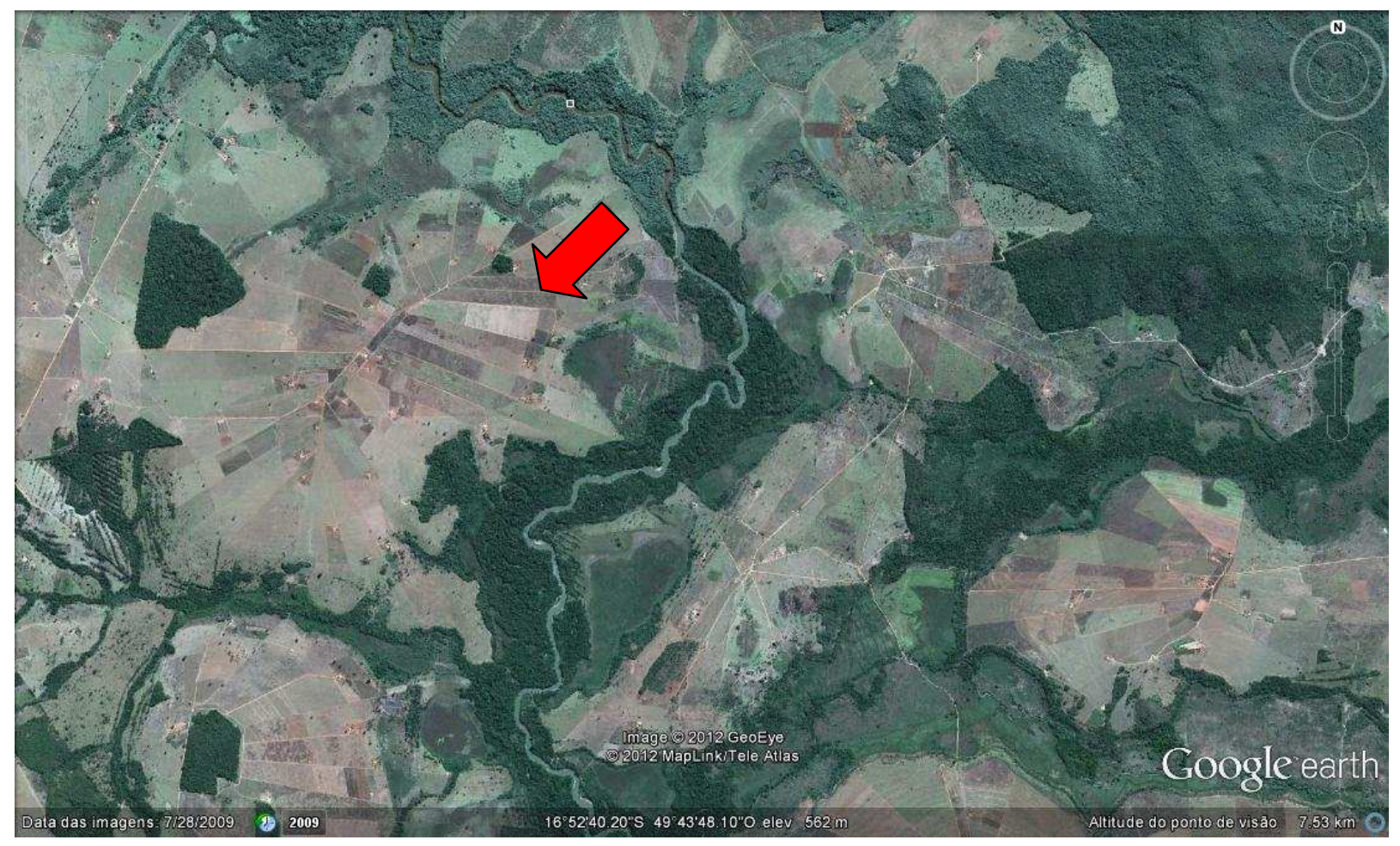

FIGURA 1- Mapa com vista aérea do assentamento Canudos.

FONTE: (Google Earth, 2009).

\section{LOCAL}

O experimento foi conduzido no Laboratório de Microbiologia da Universidade Estadual de Goiás do Câmpus Universitário de Palmeiras de Goiás.

\section{AMOSTRAGEM}

Considerando que o assentamento Canudos possui 120 residências, optou-se por coletar amostras de água de forma aleatória em 60 locais diferentes.

\section{COLETA DE AMOSTRAS}

Os procedimentos de coleta das amostras foram baseados no manual prático de análise de água, de acordo com BRASIL (2006). Anteriormente as coletas, as torneiras foram limpas com um pedaço de algodão embebido em álcool e em seguida abertas, deixando escorrer a água durante um a dois minutos e logo após, realizou-se a coleta das amostras de água.

Foram realizadas coletas de 60 amostras em diferentes áreas do assentamento Canudos, as quais foram acondicionadas em frascos estéreis de $100 \mathrm{~mL}$ e transportadas até o laboratório em caixas térmicas contendo gelo.

\section{ANÁLISE DE pH E BACTERIOLOGIA}

Paralelamente as análises bacteriológicas foram realizadas análises de $\mathrm{pH}$. $\mathrm{O}$ teste de bacteriologia utilizado foi o convencional, constando fases de pré- 
enriquecimento, isolamento em meio sólido, seleção de colônias suspeitas, identificação bioquímica.

Em cada amostra de água retirou-se um $\mathrm{mL}$ que foi transferido para tubo contendo solução salina peptonada $0,1 \%$. Esses tubos foram incubados em estufa com temperatura de $37^{\circ} \mathrm{C}$ por 24 horas. Logo após, realizou-se plaqueamentos por superfície com $0,1 \mathrm{~mL}$ em ágar padrão. Posteriormente, procedeu-se incubação a $37^{\circ} \mathrm{C}$ por 24 horas (COUSIN et al., 2001). Em seguida, transferiu-se três UFCs por placa para tubos inclinados contendo ágar ferro-açúcar triplo (TSI) e incubadas a $37^{\circ} \mathrm{C}$ por 24 horas. Após esse período, verificou-se a fermentação da glicose, da sacarose e da lactose em TSI e realizaram-se os seguintes testes bioquímicos: produção de urease, de indol, de $\mathrm{H}_{2} \mathrm{~S}$, prova do vermelho de metila.

Após a retirada de um $\mathrm{mL}$ para teste bacteriológico efetuou-se a homogeneização de cada amostra e análise de $\mathrm{pH}$. Esta medida foi determinada em potenciômetro digital PHTEK modelo pHS-3B, calibrado previamente com soluções tampão pH 4 e 7 (BRASIL, 2002).

\section{ANÁLISES ESTATÍSTICAS}

Para os dados de $\mathrm{pH}$ da água foi realizada somente a média aritmética simples, e para os dados bacteriológicos e dos relacionamentos ao questionamento, foi realizada a frequência simples (porcentagem), considerando a presença das bactérias nas amostras.

\section{RESULTADOS E DISCUSSÃO}

Observou-se uma média de 7,41 para $\mathrm{pH}$ da água que abastece 0 assentamento. Esses valores encontrados para $\mathrm{pH}$ corroboram com os valores exigidos pela portaria 518/2004 (BRASIL, 2004), que recomenda valores de $\mathrm{pH}$ entre 6,5 e 8,5 para consumo humano. A medida do $\mathrm{pH}$ é um dos testes mais importantes para a caracterização físico-química da água, e é utilizada praticamente em todas as fases do tratamento destinado a potabilidade da água (BRASIL, 2004). Valores superiores foram encontrados por SOARES et al. (2008) ao analisarem águas subterrâneas em um igarapé amazônico com média de pH em torno de 8,9.

BLANK (2010) encontraram uma média para $\mathrm{pH}$ de 6,97 em poços rasos no município de Pelotas, Rio Grande do Sul, encontrando-se portanto, esse valor dentro do permitido por BRASIL (2011) para o consumo humano. CIRNE et al. (2011) analisaram quatro amostras de água em corpos d'água do complexo Aluízio Campos e observaram que duas das amostras analisadas não atenderam aos padrões estabelecidos pela portaria 518/2004 com valores de 9,7 e 10,4. De acordo com CETESB (2015) a influência do $\mathrm{pH}$ sobre os ecossistemas aquáticos naturais, dá-se diretamente devido aos efeitos sobre a fisiologia das diversas espécies.

A análise bacteriológica da água identificou a presença de Escherichia coli, Aeromonas e Pseudomonas sp.. Sendo que, a bactéria Escherichia coli foi isolada em todas as amostras analisadas (Tabela 1). Os microrganismos transmitidos pela água possuem como principal rota de contaminação a oral-fecal, sendo disseminados a partir de esgotos não tratados ou tratados de forma inadequada. Bactérias do grupo 
coliformes são microrganismos indicadores de contaminação fecal, estando presentes no intestino humano e em animais de sangue quente, são eliminadas em grande quantidade nas fezes (MARQUEZI et al., 2010).

TABELA 1- Bactérias encontradas nas análises das 60 amostras de água que abastece $o$ assentamento Canudos

Bactérias

Escherichia coli

Aeromonas

Pseudomonas sp.

SATAKE et al. (2012), obtiveram um resultado de aproximadamente $50 \%$ das amostras fora dos padrões de potabilidade, devido a presença de Escherichia coli. BANDEIRA et al. (2011) em estudos encontraram determinação de coliformes totais em $97 \%$ das amostras e determinação de coliformes termotolerantes em $60,7 \%$ dessas.

NUNES et al. (2010), observaram que $42,8 \%$ das amostras impróprias para o consumo humano apresentando poluição fecal através da contaminação por Escherichia coli. SIQUEIRA et al., (2010) observaram que 62,5\% das amostras de água analisadas em unidades de alimentação apresentaram coliformes totais.

No Brasil, as normas referentes à qualidade microbiológica das águas são definidas pela portaria número 518 (23/03/2004) - Ministério da Saúde, capítulo IV padrão de potabilidade. Esta define que a água para o consumo humano deve ser livre de Escherichia coli ou coliformes termotolerantes com ausência em $100 \mathrm{~mL}$ ou positividade de até 5,0\% para coliformes totais (CONAMA, 1986; BRASIL, 2000).

Ao analisar os dados da fonte da água utilizada pelos moradores do assentamento, observou-se que a maioria utiliza água proveniente de poços rasos (Figura 1).

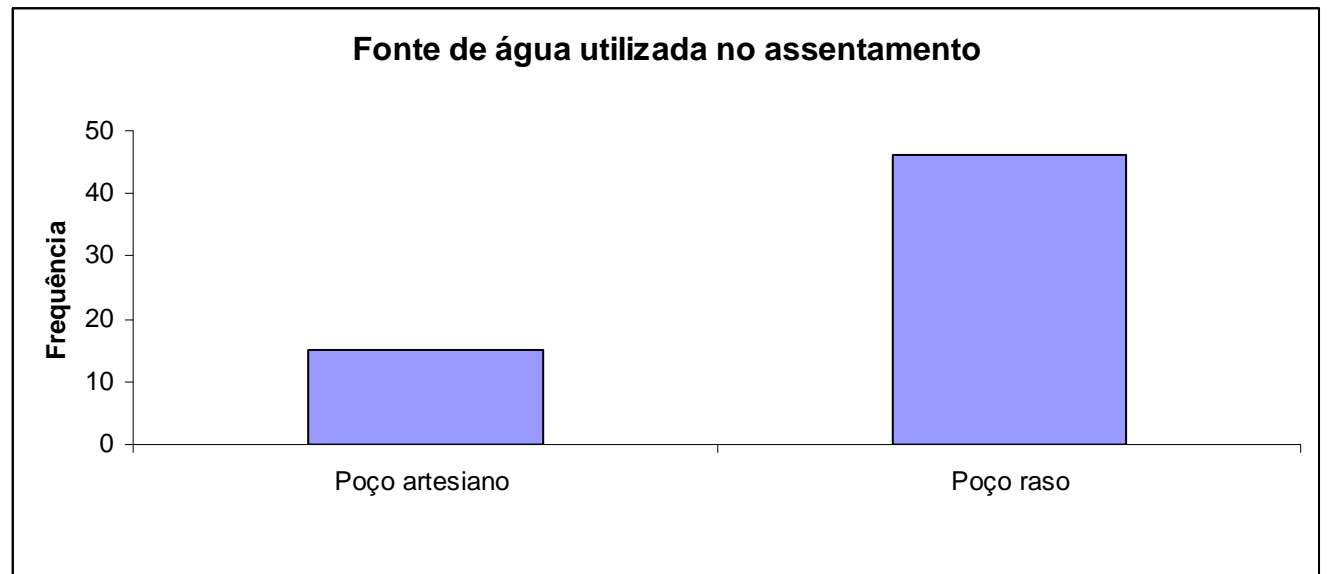

FIGURA 1- Fonte da água utilizada no assentamento Canudos, Palmeiras de Goiás 
Nos estudos realizados em propriedades rurais do município de Jaboticabal São Paulo, por NUNES et al. (2010), 100\% das fontes de abastecimento de água eram por poços rasos. BANDEIRA et al. (2011), observaram que $97 \%$ das fontes de abastecimento de água consumida por estudantes da zona rural no município de Pelotas - Rio Grande do Sul, eram poços freáticos.

KEMERICHK \& SAUCEDO (2011), ressaltam que no Brasil a utilização de águas subterrâneas ainda é feita de maneira improvisada, podendo acarretar em diversos problemas tais como, interferência de água entre poços, redução dos fluxos de base dos rios, impacto em áreas encharcadas e redução das descargas de fontes ou nascentes. Os poços abandonados podem se transformar em focos de poluição das águas.

As águas subterrâneas geralmente são menos contaminadas por fatores biológicos e químicos do que as águas superficiais, devido a não ficarem expostas aos diversos agentes poluentes, contudo, com a diversificada utilização das águas subterrâneas, torna-se cada vez mais importante realizar estudos sobre a qualidade das mesmas. Além do mais, esgotos domésticos e industriais e fertilizantes utilizados na agricultura comprometem a qualidade dessas águas (COSTA et al., 2012).

Ao analisar o tipo de animais criados nas proximidades da fonte de abastecimento do assentamento, observou-se que a maioria dos moradores possui várias espécies de animais na propriedade. Dentre as principais criações destacaramse cães, aves, bovinos, suínos (Figura 2).

Observou-se que a categoria outros foi representativa, sendo constituída por espécies como gatos, gansos, cavalos e marrecos. Vale ressaltar, que apenas dois moradores não possuíam animais em suas propriedades.

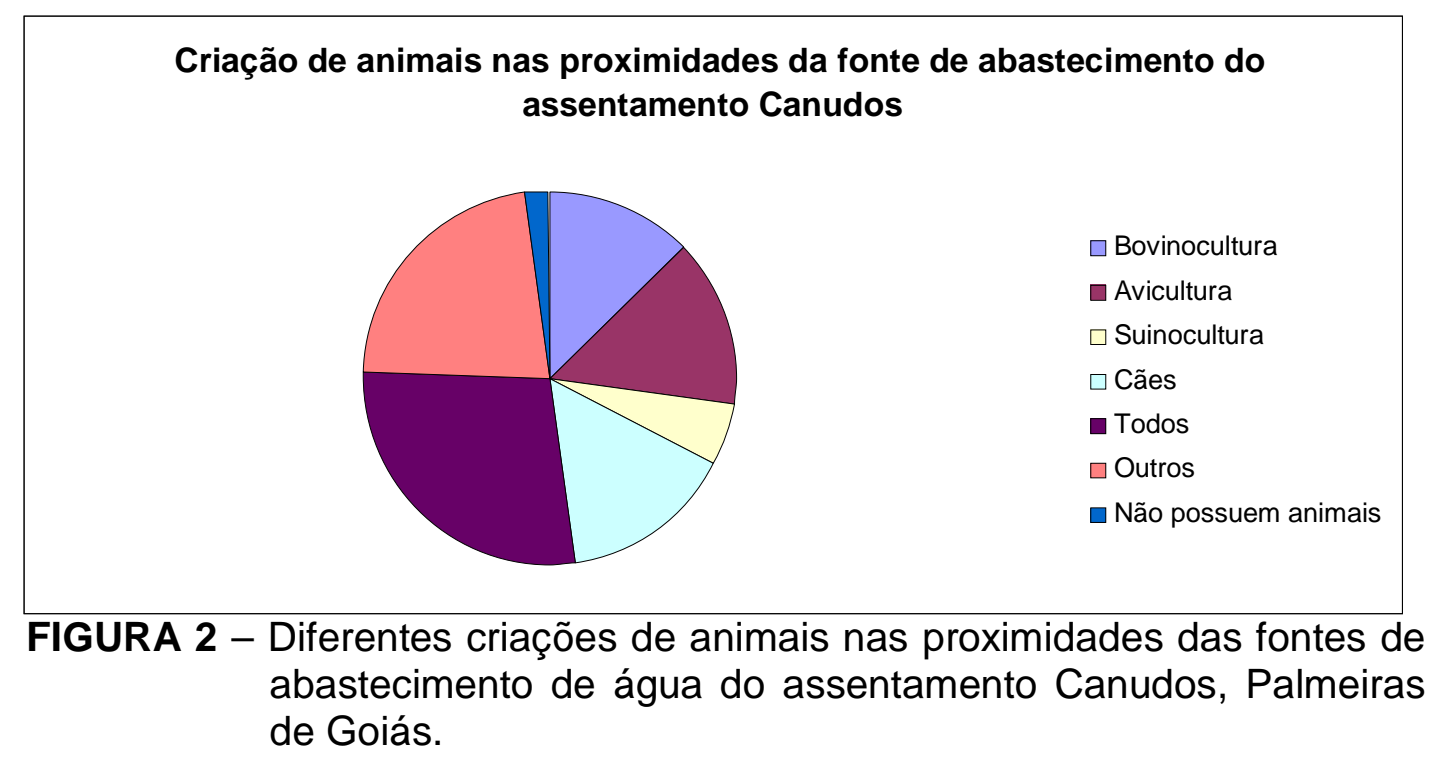

NUNES et al. (2010), constataram em pesquisa a bovinocultura como atividade agropecuária mais frequente nas propriedades rurais por eles estudadas. Já SATAKE et al. (2012), verificaram que das 29 áreas rurais estudadas, 10 criavam animais e utilizavam a água para a dessedentação. De acordo com SARTORI et al. (2010), as 
fontes de água devem estar localizadas a 30 metros dos locais das criações de animais.

O uso dos dejetos de suínos como fertilizantes é o meio mais utilizado para descartar esse resíduo, no entanto deve-se aplicar a quantidade correta para absorção do solo, com o intuito de evitar que o excesso de elementos principalmente $\mathrm{P}$, Cu e Zn, que podem atuar como agentes poluidores (CASSOL et al., 2011).

A contaminação dos recursos hídricos pela agricultura pode ocorrer de duas formas diferentes, chamadas de pontual e difusa. Na forma pontual, o principal fator é a criação de animais como suínos e bovinos, no qual os dejetos produzidos são lançados diretamente no ambiente ou aplicados à lavoura como forma de adubo orgânico. Já a forma difusa, é causada por deflúvio superficial, lixiviação e o fluxo de macroporos, dos quais o último está associado à porosidade do solo e são muito importantes dentre outras coisas na movimentação da água no solo (IRITANI et al., 2013).

Quanto à limpeza dos poços, $75 \%$ dos moradores do assentamento Canudos realizam a lavagem anualmente e somente $25 \%$ não realizam a manutenção de limpeza (Figura 3).

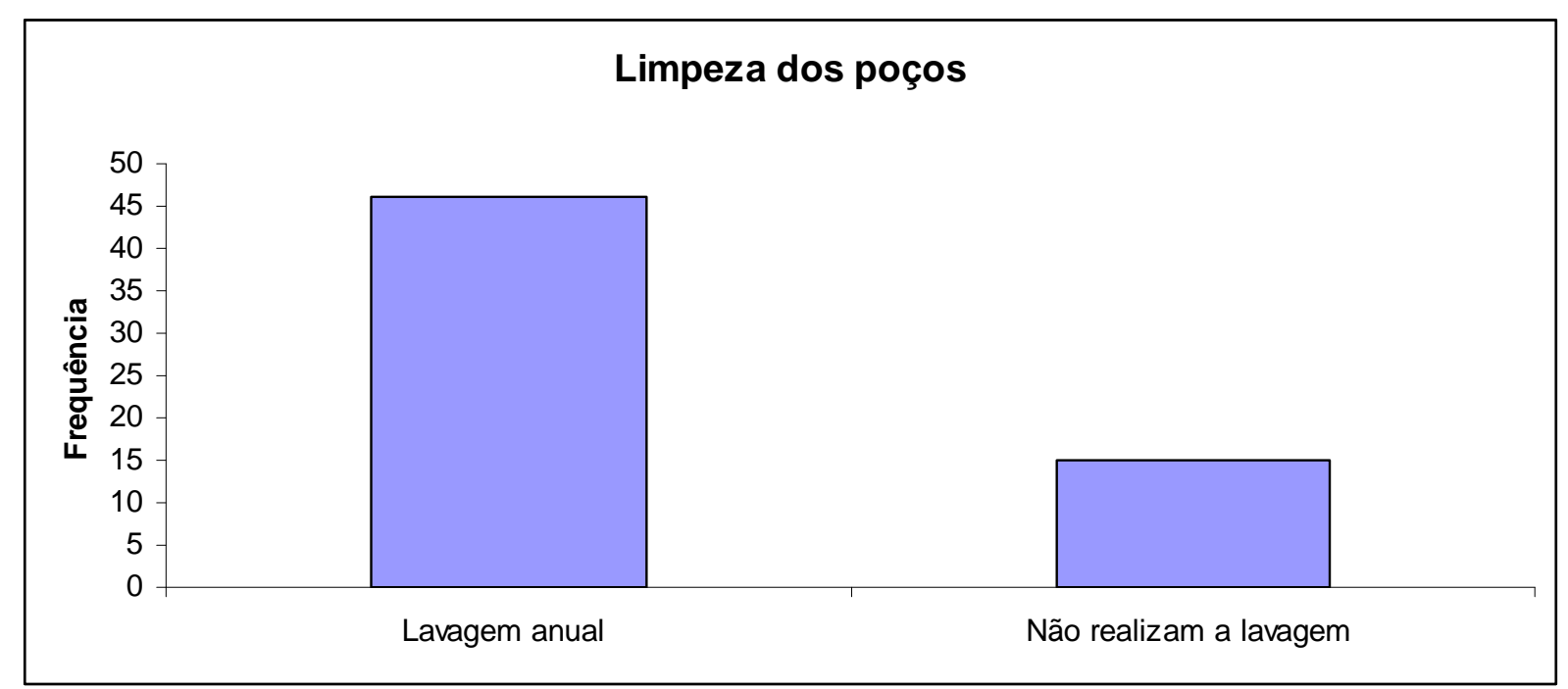

FIGURA 3 - Frequência de moradores que realizam a limpeza anual dos poços ou caixas d'água no assentamento de Canudos, Palmeiras de Goiás

YAMAGUCHI et al., (2013), destacam que as causas mais frequentes de contaminação da água proveniente de poços rasos, é devido principalmente a vedação inadequada das caixas d'água e cisternas e a carência de um programa de limpeza e desinfecção regular e periódica. Segundo a COVISA (2012) a limpeza e desinfecção de poços de pequena profundidade devem ser feita da seguinte maneira: Retirar, com auxílio de uma bomba ou manualmente, a maior quantidade de água do poço; Deixar entrar água até estabilizar o nível; O preparo da solução desinfetante deverá ser feito após a escolha do produto a ser utilizado: Água Sanitária - dois litros do produto por $\mathrm{m}^{3}$ de capacidade de água do poço, Hipoclorito de Sódio a 10\% - meio (1/2) litro do produto por $\mathrm{m}^{3}$ de capacidade de água do poço; Misturar bem a água do poço com o 
desinfetante; Esperar 12 horas e esvaziar totalmente o poço; Deixar o poço encher normalmente.

Em um estudo realizado por FALAVINHA \& DEGENHARDT (2014), ao analisarem 20 poços de captação de água, puderam observar que apenas em um realizava-se limpeza com hipoclorito de sódio para desinfecção da água. FERRAZ et al. (2014) detectaram que $50 \%$ dos poços analisados usavam hipoclorito de sódio e os outros $50 \%$ ignoram essa técnica ou não fazem nenhum tipo de tratamento.

Observou-se uma porcentagem de $49 \%$ de moradores que cultivam hortaliças na propriedade (Figura 4).

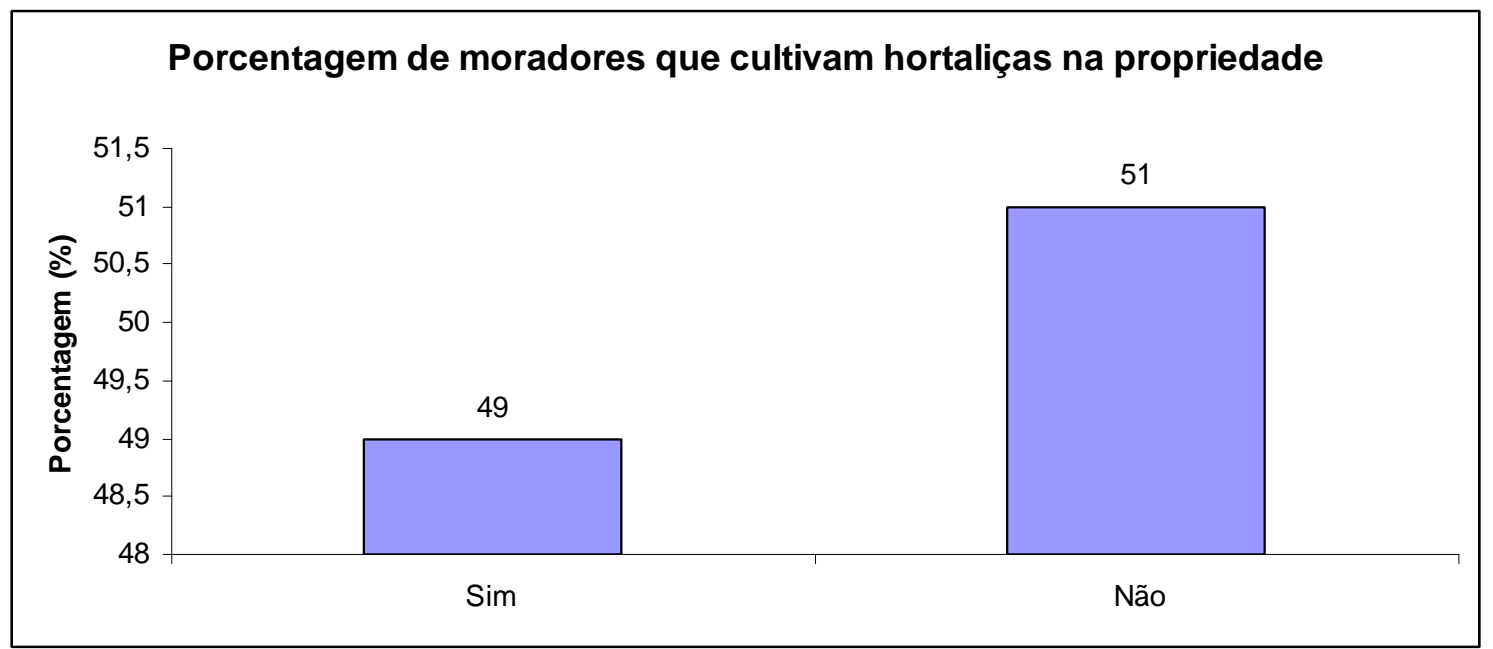

FIGURA 4- Porcentagem de moradores que cultivam hortaliças na propriedade do assentamento de Canudos, Palmeiras de Goiás

O uso de fertilizantes na agricultura provoca contaminação da água, os três principais nutrientes exigidos pelas culturas são o nitrogênio, potássio e o fósforo, sendo que destes o que apresenta maior impacto sobre as águas subterrâneas é o nitrogênio na forma de nitrato, pois possui alta mobilidade e estabilidade nos sistemas aeróbios de águas subterrâneas. Podendo provocar dois fatores adversos a saúde, a indução a metahemoglobina, principalmente em crianças, e a formação potencial de nitrosaminas e nitrosamidas carcinogênicas (SATAKE et al., 2012).

Assim também a utilização de herbicidas e inseticidas que são transportados juntamente com a água e infiltra verticalmente no solo, esse processo chama-se lixiviação. Ocasionando a poluição de águas subterrâneas, visto que uma das finalidades da água que se infiltra no solo é abastecer o lençol freático (PINTO et al., 2012). Conforme DANTAS et al. (2010), a ingestão de água contaminada com microrganismos patogênicos de origem entérica, animal ou humana são as que mais provocam doenças de veiculação hídrica.

\section{CONCLUSÃO}

A água que abastece o assentamento Canudos, localizado no município de Palmeiras de Goiás, apresentou bactérias Escherichia coli, Aeromonas e Pseudomonas sp.. 
A presença de bactérias na água pode interferir na qualidade desta e causar graves problemas à saúde da população, se forem encontradas fora dos padrões permitidos.

Entre as possíveis causas de contaminação da água por bactérias, destacam-se a limpeza inadequada dos poços que deve ser realizada anualmente; a criação de animais e 0 cultivo de hortaliças. Essas ações contribuem ativamente para contaminação de recursos hídricos, principalmente águas subterrâneas.

Dentre as causas citadas, a criação de animais e o cultivo de plantas merecem destaque, principalmente porque a maioria utiliza os dejetos dos animais como fertilizantes para as hortaliças de forma incorreta, contribuindo no processo de contaminação da água subterrânea.

\section{REFERÊNCIAS}

AGÊNCIA ESTADO. OMS: água contaminada mata 28 mil por ano no Brasil, 2008. Disponível

<http://wwo.uai.com.br/UAl/html/sessao_7/2008/06/27/em_noticia_interna,id_sessao=7 \&id_noticia=69168/em_noticia_interna.shtml>. Acesso em: 25 de fevereiro de 2014.

ARAÚJO, G.F.R.; TONANI, K.A.A.; JULIÃO, F.C.; CARDOSO, O.O.; ALVES, R.I.S., RAGAZZI, M.F.; SAMPAIO, C.F.; SEGURA-MUÑOZ, S.I. Qualidade físico-química e microbiológica da água para o consumo humano e a relação com a saúde: estudo em uma comunidade rural no estado de São Paulo. O Mundo da Saúde. São Paulo: v. 35, n. 1, p. 98-104, 2011.

BANDEIRA, F.S.; ZANI, J.L.; PICOLI, T.; PETER, C.; VIBOLT, F.F.; FISCHER, G. Qualidade microbiológica da água consumida por estudantes da zona rural de Pelotas-RS. In: XIII Encontro de Pós - Graduação da UFPel., 2011.

BLANK, D. E. Caracterização Físico-Química e Microbiológica de água de poços rasos do bairro três vendas, Pelotas-RS. In: XII ENPOS Mostra Científica, 2010.

BRASIL. Conselho Nacional do Meio Ambiente (CONAMA). Resolução $\mathbf{n}^{\circ} \mathbf{2 7 4}$ de $\mathbf{2 9}$ de nov. de 2000. Estabelece a classificação das águas doces, salobras e salinas essencial á defesa dos níveis de qualidade avaliados por parâmetros e indicadores específicos, de modo a assegurar as condições de balneabilidade. Diário oficial da República Federativa do Brasil, Brasília, 29 de nov. 2000.

BRASIL. Ministério da Saúde. Departamento de Informática do SUS. Desenvolvido pelo Ministério da Saúde. Apresenta informações sobre saúde, Brasília: MS, 2002. Disponível em: <http://www.tabnet.datasus.gov.br/cqi/ sim/obtmap.htm>. Acesso em: 25 de abril de 2014.

BRASIL. Portaria no 2914 de 12 de dez. de 2011 do Ministério da Saúde. Dispõe sobre os procedimentos de controle e de vigilância da qualidade da água para consumo humano e seu padrão de potabilidade. 2011. 
BRASIL. Ministério da Saúde. Portaria no 518, de 25 de março de 2004. Estabelece os procedimentos e responsabilidades relativas ao controle e vigilância da qualidade da água para consumo humano e seu padrão de potabilidade, e dá outras providências. Brasília. 2004.

BRASIL. Ministério do Meio Ambiente, Conselho Nacional de Meio Ambiente (CONAMA). Resolução no 357 de 17 de mar. de 2006. Dispõe sobre a classificação dos corpos de água e diretrizes ambientais para o seu enquadramento, bem como estabelece as condições e padrões de lançamento de efluentes, e dá outras providências. 2006.

CARVALHO, G.D.; NASCIMENTO, J.B.; MOREIRA, C.A.; LEANDRO, W.M. Indicadores de sustentabilidade em função de diferentes culturas cultivadas em assentamento de reforma agrária no município de Guapó, GO. Revista Brasileira de Agroecologia, v. 2, n. 2, p. 1196 - 1199, 2007.

CASSOL, P.C.; SILVA, D.C.P.; ERNANI, P.R.; FILHO, O.K.; LUCRÉCIO, W. Atributos químicos em latossolo vermelho fertilizado com dejeto suíno e adubo solúvel. Revista de Ciências Agroveterinárias. Lages: v.10, n.2, p.103-112, 2011.

CASTRO, L. R. dos S.; CARVALHO, J. S.; VALE, V. L. C. Avaliação microbiológica de diferentes marcas de água mineral. Revista Baiana de Saúde Pública. v.34, n.4, p.835-844, 2010.

CETESB - Centro Tecnológico de Saneamento Básico. Disponível em: <www.cetesb.sp.gov.br>. Acesso em 23 jul. 2015.

CIRNE, J. R. R.; SILVA, L.F.N.; NASCIMENTO, J.C.; ALVES, R.V.; ANDRADE, L.R.S.; SOUZA, M.Z.S. Avaliação da qualidade físico-química dos corpos d'água do complexo Aluízio Campos. Revista de Biologia e Farmácia. v. 6, n. 1, 2011.

CONAMA. Conselho Nacional do Meio Ambiente (CONAMA). Resolução n. 20, 18 de junho de 1986. Brasília: Mistério do Meio Ambiente, 1986.

COSTA, C.L.; LIMA, R.F.; PAIXÃO, G.C.; PANTOJA, L.D.M. Avaliação da qualidade das águas subterrâneas em poços do estado do Ceará, Brasil. Ciências Biológicas e da Saúde. Londrina: v. 33, n. 2, p. 171-180, 2012.

COUSIN, M.A., JAY, J.M.; VASAVADA, P.C. Psychrotrophic microorganisms. In: DOWNES, F. P.; ITO, K. (eds.). Compendium of methods for the microbiological examination of foods. 4 ed. Washington: APHA, p. 159-166, 2001.

COVISA, Coordenação de Vigilância em Saúde. Orientação para desinfecção caixa d'água e poço. Prefeitura de São Paulo, 2012. Disponível em: < http://www.prefeitura.sp.gov.br/cidade/secretarias/upload/chamadas/orientacoes_para 
desinfeccao_caixa_de_agua_e_poco_1296855386.pdf>. Acesso em 30 de janeiro de 2014.

DANTAS, A. K.D.; SOUZA, C.; FERREIRA, M.S.; ANDRADE, M.A.; ANDRADE, D.; WATANABE, E. Qualidade microbiológica da água de bebedouros destinada ao consumo humano. Revista Biociências, UNITAU, v. 16, n. 2, p. 132 - 138, 2010.

FALAVINHA, G.; DEGENHARDT, R. Qualidade microbiológica da água de nascentes e poços da comunidade de Barro Branco, Capinzal - SC. Unoesc \& Ciência. Joaçaba: v. 5, n. 2, p. 209-216, 2014.

FERRAZ, A.G.; PEREIRA, S.V.; GONÇALVES, E.A.P. Intervenções simplificadas e de baixo custo na eliminação de micro-organismos patogênicos em poços que abastecem instituições de longa permanência para idosos em Recife-PE. $V$ Congresso Brasileiro de Gestão Ambiental. IBEAS-Instituto Brasileiro de Estudos Ambientais, Belo Horizonte, 2014.

GOMES, M. A. F. Água: sem ela seremos o planeta Marte de amanhã. Embrapa Meio Ambiente, mar. 2011. Disponível em: <http://webmail.cnpma.embrapa.br/down_hp/464.pdf>. Acesso em: 28 de janeiro de 2014.

GOOGLE Earth (2009), software livre acessado dia 30 de setembro de 2012.

INCRA GOIAS. Canudos. Blog da superintendência regional do INCRA em Goiás, 2011. Disponível em: <http://incragoias.wordpress.com/tag/canudos/>. Acesso em: 04 set. 2012.

IRITANI, M.A.; PENTEADO, R.D.; EZAKE, S.; ODA, G.H. Proposta de classificação das fontes potenciais de contaminação da água subterrânea. Revista do Instituto Geológico. São Paulo: v. 34, n. 2, 2013.

KEMERICHK, P.D.C.; SAUCEDO, E.M. Saúde e condições sócio-ambientais de usuários de água subterrânea no bairro Nossa Senhora do Perpétuo Socorro de Santa Maria - RS. Engenharia Ambiental. Espírito Santo do Pinhal: v. 8, n. 3, p. 38-50, 2011.

LIMA, J.A.; DAMBROS, M.V.R.; ANTONIO, M.A.P.M.; JANZEN, J.G.; MARCHETTO, M. Potencial da economia de água potável pelo uso de água pluvial: análise de 40 cidades da Amazônia. Engenharia Sanitária e Ambiental. v. 16, n. 3, 2011.

NUNES, A.P.; LOPES, L.G.; PINTO, F.R.; AMARAL, L.A. Qualidade da água subterrânea e percepção do s consumidores em propriedades rurais. Nucleus, v. 7, n. 2, 2010. 
MARQUEZI, M.C.; GALLO, C.R.; DIAS, C.T.S. Comparação entre métodos para a análise de coliformes totais e E. coli em amostras de água. Revista do Instituto Adolfo Lutz. v. 69, n. 3, p. 291-296, 2010.

PINTO, L.V.A.; ROMA, T.N.; BALIEIRO, K.L.C. Avaliação qualitativa da água de nascentes com diferentes usos do solo em seu entorno. Cerne, v. 18, n. 3, p. 495-505, 2012.

RHEINHEIMER, D.S.; GONÇALVES. C.S.; BORTOLUZZI, B.C.; PELLEGRINI, J.B.R.; SILVA, J.L.S.; PETRY, C. Qualidades de águas subterrâneas captadas em fontes em função da presença de proteção física e de sua posição na paisagem. Engenharia Agrícola. Jaboticabal: v. 30, n. 5, p. 948-957, 2010.

SANTOS, J.O.; SANTOS, R.M.S.; GOMES, M.A.D.; MIRANDA, R.C.; NÓBREGA, I.G.M. A qualidade da água para o consumo humano: uma discussão necessária. Revista Brasileira de Gestão Ambiental. v. 7, n. 2, p. 19-26, 2013.

SARTORI, J.I.; VELHO, A.B.; PISTORELLO, N.; TELES, A.; CABERLON, M.V.; TAIAROL, J. Saneamento básico rural. Prefeitura de Caxias, 2010. Disponível em: < https://www.caxias.rs.gov.br/_uploads/agricultura/saneamento_basico_rural.pdf>. Acesso em: 30 de janeiro de 2014.

SATAKE, F.M.; ASSUNÇÃO, A.W.; LOPES, L.G. AMARAL, L.A. Qualidade da água em propriedades rurais situadas na bacia hidrográfica do córrego Rico, Jaboticabal - SP. ARS Veterinária. Jaboticabal: v. 28, n. 1, p. 48-55, 2012.

SILVA, R. de C.; ARAÚJO, T. M. de. Qualidade da água do manancial subterrâneo em áreas urbanas de Feira de Santana (BA). Ciência \& Saúde Coletiva, v. 8, n. 4, p. 10191028, 2003.

SIQUEIRA, P.L.; SHINOHARA, N.K.S.; LIMA, R.M.T.; PAIVA, J.E.; FILHO, L.J.L.; CARVALHO, I.T. Avaliação microbiológica da água de consumo empregada em unidades de alimentação. Revista Ciência e Saúde Coletiva. v. 15, n. 1, p. 63-66, 2010.

SOARES, M.J.S.; JUNIOR, G.C.S.; QUINTÃO, S.L.S.; LAGE, I.C.; BIAZZI, E. Hidroquímica de águas superficiais e subterrâneas em Igarapé Amazônico. In: Congresso Brasileiro de Águas Subterrâneas, 10, São Paulo, 2008.

YAMAGUCHI, M.U.; CORTEZ, L.E.R.; OTTONI, L.C.C.; OYAMA, J. Qualidade microbiológica da água para consumo humano em instituição de ensino de Maringá PR. O Mundo da Saúde. São Paulo: v. 37, n. 3, p. 312-320, 2013. 